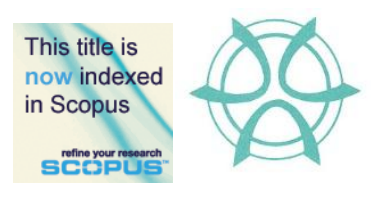

PLANNING MALAYSIA:

Journal of the Malaysian Institute of Planners

Volume XII (2014), Page 81 - 104

\title{
INTEGRATING CLIMATE CHANGE MITIGATION AND ADAPTATION INTO SPATIAL PLANNING: DEVELOPING CRITERIA FOR SPATIAL PLAN EVALUATION IN THE SELANGOR RIVER BASIN
}

\author{
Chee Ping Ngang ${ }^{1}$, Joy Jacqueline Pereira ${ }^{2}$ \& Halimaton Saadiah \\ Hashim $^{3}$ \\ 1,2\&3 Institute for Environment and Development (LESTARI), \\ UNIVERSITI KEBANGSAAN MALAYSIA
}

\begin{abstract}
Spatial planning practice in Malaysia has given greater prominence to environmental matters since the amendment of the Town and Country Planning Act 1976 in 1995, in which sustainable development has become the core emphasis of all planning policies and plans. However, elements of climate change, which require being addressed in strategic planning, have not been explicitly incorporated into spatial plans that cover urban and rural areas at both state and local levels. This study presents a framework for the evaluation of the content of spatial plans in response to climate change adaptation and mitigation in the case of the Selangor River Basin, which may be considered the life support for the Kuala Lumpur Conurbation, the largest urban mega region in Malaysia. A content analysis of national, state and local level spatial plans reveals that the overall quality of plans is higher at the national level, but gradually declines towards lower tier plans, and that generally an equal emphasis has been paid to both climate change mitigation and adaptation. The findings support the argument that spatial planning provides a platform for coordinating mitigation and adaptation responses through its sustainable development policies, however, there is a need to reframe the scope of sustainable development in the country for this purpose.
\end{abstract}

Keyword: Spatial planning, spatial plan, plan evaluation, climate change

${ }^{1}$ Postgraduate Student (Doctor of Philosophy), LESTARI, UKM. Email: cheepn1974@gmail.com

${ }^{2}$ Professor, LESTARI, UKM. Email: joy@ukm.my

${ }^{3}$ 3Senior Fellow, LESTARI, UKM. Email: drhalimaton@ gmail.com 
Chee Ping Ngang, Joy Jacqueline Pereira \& Halimatonsaadiah Hashim

Integrating Climate Change Mitigation And Adaptation Into Spatial Planning: Developing Criteria For

Spatial Plan Evaluation In The Selangor River Basin

\section{INTRODUCTION}

The Malaysian National Policy on Climate Change (NPCC) was approved by the Cabinet in November 2009, and serves as a framework to mobilise and guide government agencies, industries, communities, and other stakeholders in addressing the challenges of climate change in an integrated manner. One of the objectives of the Malaysian NPCC is to integrate climate change responses through national policies, plans and programmes (NRE 2009), including spatial plans. Spatial planning practice in Malaysia has given greater prominence to environmental matters since the Town and Country Planning Act 1976 was amended in 1995, in order to make sustainable development the core emphasis of all planning policies and plans (Bruton, 2007). Nonetheless, climate change is still considered as a relatively new challenge to be engaged in terms of spatial planning in Malaysia.

The aim of this study is to present a framework for the evaluation of the content of spatial plans in response to both climate change adaptation and mitigation, using the case of the Selangor River Basin in Malaysia as an example. Two research questions are addressed in this research, which are: i) To what extent have spatial plans in the Selangor River Basin prepared for climate change? Are there variations between spatial plans at the national, state and local levels in this context? ii) Do spatial plans pay an equal amount of attention to climate change mitigation and adaptation? The answers to these questions will help to identify gaps in the existing spatial planning responses towards climate change, and guidance for future reviews of spatial planning policies. This study commences with a brief discussion on the relationships between spatial planning and climate change, followed by an explanation of the conceptual framework for spatial plan evaluation based on both the relationships and the methodology used in this study. Finally, this research describes the results of the application of the method on the Selangor River Basin.

\section{SPATIAL PLANNING AND CLIMATE CHANGE}

Spatial planning is a tool or decision making process to steer land use changes and future distribution of activities in space by coordination of different relevant socio economic and environment objectives (European 
Commission, 1997). It is a generic term that refers to the various types of planning practices at different planning levels or spatial scales (SchmidtThome, 2006). With the emerging issue of climate change, spatial planning plays a vital role in responding to both the causes of climate change (through climate change mitigation) and the impacts of unavoidable climate change (through climate change adaptation) (Davoudi et al., 2009). Spatial planning, through its organization of land uses, may help to reduce greenhouse gases emission, particularly through the planning of land uses, transportation and waste management (Robinson, 2006; DCLP UK, 2007; Wheeler et al., 2009; Blanco \&Alberti, 2009; Savacool\& Brown, 2010). On the other hand, planning against the unavoidable impact of climate change can be realized particularly in water, flood and coastal management (Boult, 2009; Wilson \& Piper, 2010; Nicholls, 2011; Erol\&Randhir, 2012). However, this may require a reframing of spatial planning interventions, with a renewed and revised interpretation of sustainable development (Wilson and Piper, 2010). Initially, climate change was mainly integrated into spatial planning in the form of various mitigation strategies (Robinson, 2006; Levett, 2006), however, in this century, the current focus has begun to shift from mitigation strategies to adaptation strategies. Scholars have also considered the possible role of spatial planning in the coordination and development of effective mitigation and adaptation options in an integrated manner through sustainable development policies (Bulkeley, 2006; Biesbroek et al., 2009).

Sectors in spatial planning that can contribute to the mitigation of climate change are: land use, transportation, energy planning and waste management. On the other hand, climate change adaptation is more related to waste resources, food and coastal management. Biodiversity conservation and urban environment are two sectors that can integrate both mitigation and adaptation responses (Wilson and Piper, 2010). The role of spatial planning in climate change mitigation, climate change adaptation and the integration between mitigation and adaptation are summarized in Table 1.

Table 13: Linkages between spatial planning and climate change based on literature

\begin{tabular}{|c|c|c|}
\hline & Policies in Spatial Planning & Literature \\
\hline & Land Use & \\
\hline 1. & $\begin{array}{l}\text { Development away from vulnerable } \\
\text { area (A) }\end{array}$ & $\begin{array}{l}\text { Schmidt- Thome (2006), Keeffe (2009), } \\
\text { Peltonen et al. (2005), Bulkeley (2006) }\end{array}$ \\
\hline 2. & $\begin{array}{l}\text { Disaster resistant land use and } \\
\text { building code (A) }\end{array}$ & $\begin{array}{l}\text { Tang et al. (2010), Boult (2009), Keeffe } \\
\text { (2009), Kabat (2009) }\end{array}$ \\
\hline 3. & $\begin{array}{l}\text { Control of urban service/growth } \\
\text { boundaries/ concentrated }\end{array}$ & $\begin{array}{l}\text { Tang et al. (2010), Wheeler et al. } \\
\text { (2009), Robinson (2006) }\end{array}$ \\
\hline
\end{tabular}


Chee Ping Ngang, Joy Jacqueline Pereira \& Halimatonsaadiah Hashim

Integrating Climate Change Mitigation And Adaptation Into Spatial Planning: Developing Criteria For Spatial Plan Evaluation In The Selangor River Basin

development/ reduce urban sprawl

(M)

4. $\quad$ Mixed use /compact development (M)

Permana et al. (2013), Tang et al. (2010), Brown et al. (2009), Sovacool\& Brown (2010), Wheeler et al. (2009)

5. Urban regeneration/ infill development/ brown field development $(\mathrm{M})$

6. Land use and urban design that retain Jusuf et al. (2007), Wong and Chen natural area $(\mathrm{M} \& \mathrm{~A})$

\section{Transportation}

7. Transit-oriented development and corridor improvements (M) Tang et al. (2010), Wheeler et al. (2009), Robinson (2006) (2005)

Brown et al. (2009), Wendea et al. (2010), Tang et al. (2010)

8. Alternative transportation strategies / rail and bus network planning/ Integrated transportation system (M) Brown et al. (2009), Sovacool\& Brown (2010), Wheeler et al. (2009), Bulkeley (2006), Tang et al. (2010), Levett (2006)

9. Parking standards adjustment (M) Levett (2006), Tang et al. (2010) Energy

10. Energy efficiency planning (M) Wendea et al. (2010), Wheeler et al. (2009), Tang et al. (2010)

11. Renewable energy planning (M) Tang et al. (2010), Bulkeley (2006), Brown et al. (2009), Sovacool\& Brown (2010), Wendea et al. (2010), Blanco \&Alberti (2009)

\begin{tabular}{|c|c|c|}
\hline & \multicolumn{2}{|l|}{ Waste } \\
\hline 12. & $\begin{array}{l}\text { Planning for landfill with methane } \\
\text { capture strategy (M) }\end{array}$ & Wheeler et al. (2009), Tang et al. (2010) \\
\hline \multirow[t]{2}{*}{13.} & $\begin{array}{l}\text { Planning for zero waste reduction and } \\
\text { high recycling strategy }(\mathrm{M})\end{array}$ & Tang et al. (2010) \\
\hline & \multicolumn{2}{|l|}{ Water } \\
\hline 14. & Water use efficiency planning (A) & Wilson et al. (2010) \\
\hline 15. & $\begin{array}{l}\text { Watershed based land management/ } \\
\text { River basin management/ Ecosystem } \\
\text { based land management (A) }\end{array}$ & $\begin{array}{l}\text { Biesbrock et al. (2009), Wilson \& Piper } \\
\text { (2010), Tang et al. (2010) }\end{array}$ \\
\hline 16. & $\begin{array}{l}\text { Storm water management/ Flood } \\
\text { mitigation }(\mathrm{A})\end{array}$ & $\begin{array}{l}\text { Blanco \&Alberti (2009), Fleishhauer } \\
\text { and Koh (2009), Boult (2009), Wilson \& } \\
\text { Piper (2010), Tang et al. (2010), Erol } \\
\text { and Randhir (2012) }\end{array}$ \\
\hline 17. & $\begin{array}{l}\text { Water demand management planning } \\
\text { (A) }\end{array}$ & Beck \&Bernauer (2011) \\
\hline 18. & $\begin{array}{l}\text { Water supply management planning } \\
\text { (A) }\end{array}$ & Beck \&Bernauer (2011) \\
\hline & \multicolumn{2}{|l|}{ Coast } \\
\hline 19. & Coastal zone protection (A) & Blanco \&Alberti (2009), Fleishhauer \\
\hline
\end{tabular}


PLANNING MALAYSIA

Journal of the Malaysia Institute of Planners (2014)

and Koh (2009), Nicholls (2011)

\begin{tabular}{lll}
\hline & Urban Design/ Building & and Koh (2009), Nicholls (2011) \\
\hline 20. & $\begin{array}{l}\text { Green building codes/ standards (with } \\
\text { climate resistant and energy } \\
\text { efficiency/ capture natural climate) } \\
\text { (M\&A) }\end{array}$ & $\begin{array}{l}\text { Wilson \& Piper (2010), Brown et al. } \\
\text { (2009), Wendea et al. (2010), Wheeler } \\
\text { et al. (2009), Blanco \&Alberti (2009), } \\
\text { Fleishhauer and Koh (2009), Tang et al. } \\
(2010)\end{array}$ \\
\hline 21. $\begin{array}{l}\text { Urban design that reduce urban heat } \\
\text { island effect (M\&A) }\end{array}$ & $\begin{array}{l}\text { Giridharan et al. (2007), Stone (2005) } \\
\text { Biodiversity }\end{array}$ \\
\hline 22. & $\begin{array}{l}\text { Creation of conservation zones or } \\
\text { protection areas (forest, natural } \\
\text { habitat, food, etc) (M\&A) }\end{array}$ & $\begin{array}{l}\text { Wilson \& Piper (2010), Wendea et al. } \\
\text { (2010), Escobedo et al. (2010), Tang et } \\
\text { al. (2010). }\end{array}$ \\
\hline 23. & $\begin{array}{l}\text { Reforestation/ Reduce land clearing } \\
\text { (M\&A) }\end{array}$ & $\begin{array}{l}\text { Wilson \& Piper (2010), Driscoll et al. } \\
\text { (2010) }\end{array}$ \\
\hline 24. $\begin{array}{l}\text { Creation of ecological linkages } \\
\text { (M\&A) }\end{array}$ & $\begin{array}{l}\text { Wilson \& Piper (2010), Opdam (2009), } \\
\text { Barbour (2010) }\end{array}$ \\
\hline 25. & $\begin{array}{l}\text { Expand parks and other green spaces } \\
\text { in/ around cities, plant trees/ gazette } \\
\text { parks (M\&A) }\end{array}$ & $\begin{array}{l}\text { Wendea et al. (2010), Akbari (2002), } \\
\text { Keeffe (2009) }\end{array}$ \\
\hline
\end{tabular}

\section{CONCEPTUAL FRAMEWORK FOR SPATIAL PLAN EVALUATION}

The spatial plan evaluation exercise has evolved from developing several alternative plans as a part of the plan making process; and evaluating the conformance and performance of plans; to evaluating the quality of a subject or element in a plan (Baer 1997). The evaluation of planning is a necessary exercise, since it can contribute to a better planning practice. It may also guide the evaluation of existing plans, the preparation of new plans or the updating of existing plans (Berke and Godschalk, 2009). Plan quality is increasingly being used, both as an outcome variable for assessing the planning process, and as a causal variable for assessing the plan implementation process (Brody, 2003a).

For the evaluation of the quality of a subject in a plan, Kaiser et al. (1995) had proposed plan components, such as facts, goals, policies and evaluations as the criteria for planning evaluation. Consequently, this was also highlighted in studies by Berke and French (1994) and Brody (2003a). Some scholars have also introduced additional characteristics to the four criteria, such as inter-organizational coordination, capabilities and 
Chee Ping Ngang, Joy Jacqueline Pereira \& Halimatonsaadiah Hashim

Integrating Climate Change Mitigation And Adaptation Into Spatial Planning: Developing Criteria For Spatial Plan Evaluation In The Selangor River Basin

implementation (Brody, 2003b), plan analytical quality and plan consistency (Norton, 2008) and awareness analysis and actions (Tang et al., 2010).

A number of previous studies have focused on the evaluation of climate change integration in spatial plans (Lu and Stead 2013; Pinto and Martins 2013; Pettersson and Keskitalo 2013; Grazi and Bergh 2008; Urwin and Jordan 2008; Tang et al. 2010; Wheeler 2008; Wilson 2006). However, most of the studies focus on either mitigation or adaptation, without considering the holistic integration of both mitigation and adaptation elements in the spatial plans.

The conceptual framework for this study evaluates the quality of climate change elements (both mitigation and adaptation) in spatial plans based on the combination of plan components emphasized by Kaiser et al. (1995), and the Planning Process Model proposed by Baer (1997; Figure 1), on the basis that a plan is a document outcome from the planning process. As an addition to the four plan components by Kaiser et al. (1995), a separate component on the analysis is proposed based on the Planning Process Model (Baer, 1997), as we find that spatial plan preparation gives favourable attention to analysing past trends, future trends, land suitability analysis and other multi-criteria data analysis.

The fact component refers to the presentation of data and the spatial implication of climate change, either explicitly or implicitly. The criteria for the fact component are identified based on the projected climate change stipulated in National Communication 2 (NC2) Malaysia, i.e., temperature rise, changing rainfall amount (increase or decrease in different localities), changing rainfall intensity and sea level rise. The analysis component refers to the analysis of climate change scenarios at the local level and the impact of activities at the regional and local scale, contributing to climate change and vulnerability assessment at the local level. The goal component of spatial plans is evaluated based on its emphasis towards four sustainable development principles set out by Berke and Conroy (2000), namely, harmony with nature, liveable built environment, place based economy and equity. The policy component is measured through a series of criteria or relationship between spatial planning and climate change (mitigation and adaptation) that allow for quantitative assessment and analysis of plan quality. Lastly, the implementation and evaluation component involves the setting of timelines for actions, identifying responsible organizations for actions, sources of funding and setting criteria for plan monitoring. All these items are important for the coordination and implementation of actions between agencies. 


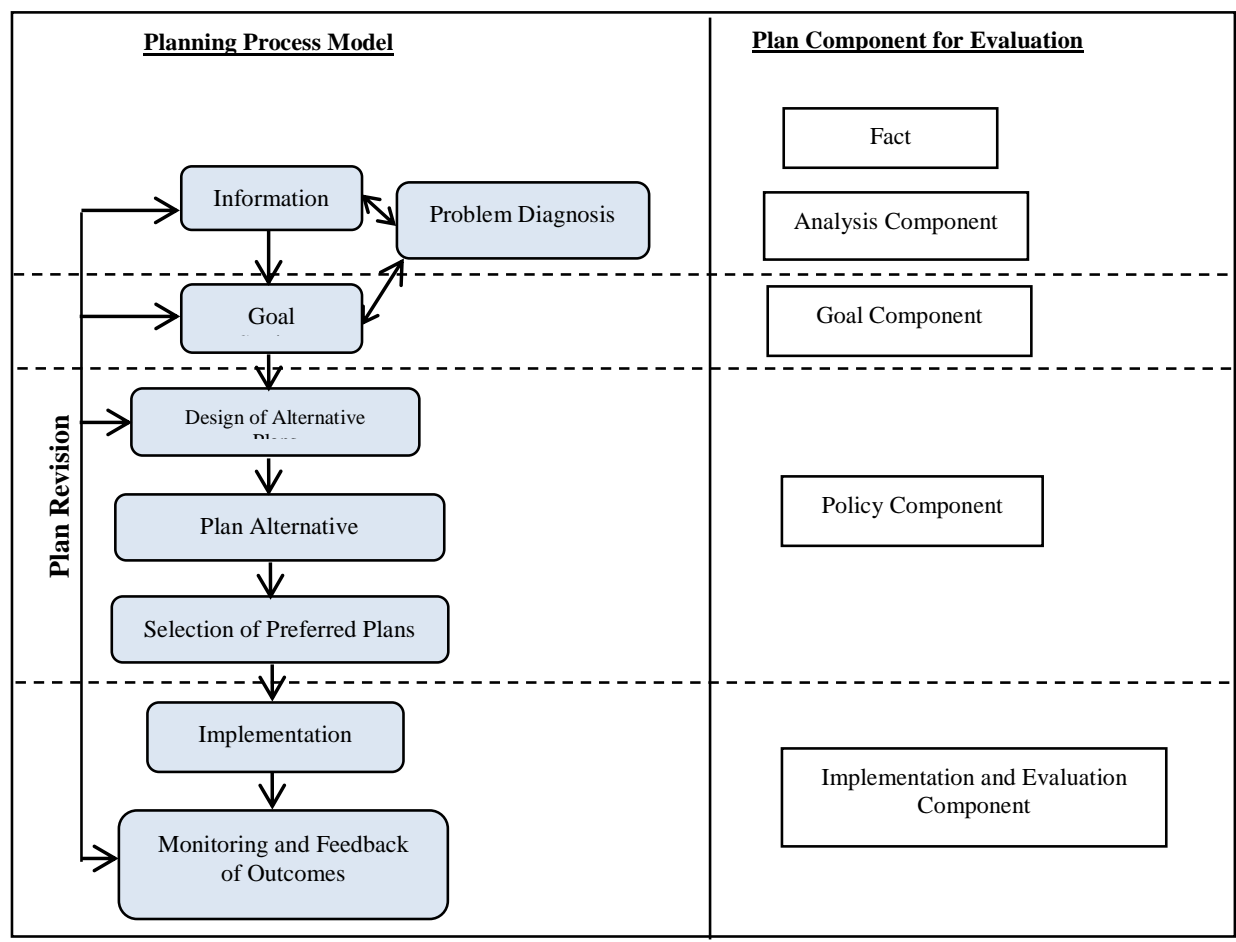

Figure 16: A conceptual framework of planning process and plan components Planning Process Model adapted from Baer (1997)

\section{METHODOLOGY}

This study uses content analysis to evaluate the integration of climate change in spatial planning (via spatial plan) in the case of the Selangor River Basin. Previously, numerous studies had evaluated the quality of a certain subject in spatial planning, e.g., urban sprawl reduction (Norton, 2008; Brody et al., 2006), natural hazards (Berke and French, 1994; Brody, 2003a), state planning mandates (Berke and French, 1994), sustainable development (Berke and Conroy, 2000), stakeholder participation (Brody, 2003b), and climate change (Lu and Stead, 2013; Wilson, 2006; Wheeler, 2008; Tang et al., 2010). For the evaluation of climate change integration in spatial planning, scholars had mainly focused on two methods, which are questionnaire surveys (Gurran et al., 2012; Robinson, 2005), or content analysis (Lu and Stead, 2013; Wilson, 2006; Wheeler, 2008; Tang et al., 
Chee Ping Ngang, Joy Jacqueline Pereira \& Halimatonsaadiah Hashim

Integrating Climate Change Mitigation And Adaptation Into Spatial Planning: Developing Criteria For

Spatial Plan Evaluation In The Selangor River Basin

2010). Comparatively, content analysis has been widely applied based on the assumption that a plan is the outcome of the planning process, and serves as a basic guidance for the planning practice (Faludi 2000).

The population of this study involves six spatial plans at three different administrative levels in the Selangor River Basin, which are: the National Physical Plan (or NPP1 (2005) and NPP2 (2010)) at the national level, the Selangor State Structure Plan (SSSP) at the state level, and the Selayang Municipal Council Local Plan (SMCLP), Kuala Selangor District Local Plan (KSDLP) and Hulu Selangor District Local Plan (HSDLP) at the local level. The Selangor River Basin is located in the State of Selangor, Peninsular Malaysia, with a total area of $2,200 \mathrm{~km}^{2}$. It is the third largest river basin in Selangor after the Langat River Basin and Bernam River Basin (Selangor State Government, 2007). This river basin was selected because it is the most important water resource in the state of Selangor and the Federal Territories of Kuala Lumpur and Putrajaya. The Selangor River supplies $60 \%$ of the water used in Klang Valley (the most developed urban mega region in Peninsular Malaysia). The main challenges for the planning and management of the Selangor River Basin is the increasing demand for water due to the rapid population growth and brisk economic development, coupled by a decrease in rainfall levels, a decrease in monthly river flow levels and a decrease in water supply levels (NRE, 2011).

For plan evaluation, initially, the characteristics of a high quality spatial plan with climate change elements were defined. This was followed by the construction of a plan quality evaluation protocol based on the combination of the conceptual framework defined earlier and the relationships between spatial planning and climate change (Table 2). Spatial plans were evaluated based on the five plan components with a total of 43 criteria. The criteria for each plan component were scored on either a $0-2$ scale, or a $0-1$ scale. A content analysis was applied to calculate the plan component quality and total plan quality for each spatial plan. Higher summed scores indicate that the plan places more emphasis on relevant components, following the plan quality evaluation approach from previous studies (Berke, 1996, 1998; Berke and Conroy, 2000; Brody, 2003a, 2003b, 2006; Norton, 2008; Tang et al., 2010). To increase reliability for the content analysis, the plans were evaluated by two coders independently, and each spatial plan was evaluated three times. The evaluations were compared, and inconsistently scored criteria were revisited to yield a score that was agreed upon. The results were then further verified by the senior staff 
members of the Department of Town and Country Planning, which are responsible for the preparation of spatial plans at the three spatial scales.

Table 14: Criteria for spatial plan evaluation

\begin{tabular}{|c|c|c|c|}
\hline & $\begin{array}{l}\text { Parameter/ } \\
\text { Component }\end{array}$ & Criteria & Scope \\
\hline 1. & $\begin{array}{l}\text { Fact component } \\
0=\text { not present, } 1= \\
\text { present but not } \\
\text { detailed, } 2=\mathrm{present} \\
\text { and detailed/with } \\
\text { indicative map } \\
\text { (national)/diagram or } \\
\text { illustration (state)/map } \\
\text { (local) }\end{array}$ & $\begin{array}{l}\text { Explicit reference } \\
\text { - Climate change as issues } \\
\text { - Data (scenario, projection, maps) } \\
\text { - Spatial implication (explanation, } \\
\text { maps) } \\
\text { Implicit reference } \\
\text { - Temperature (urban heat island } \\
\text { effect) } \\
\text { - Changing rainfall amount (flood } \\
\text { or drought/ water stress area) or } \\
\text { changing rainfall intensity } \\
\text { (extreme weather) } \\
\text { - Rise in sea level }\end{array}$ & $\begin{array}{l}\text { - Issues } \\
\text { - Presentation of } \\
\text { data }\end{array}$ \\
\hline 2. & $\begin{array}{l}\text { Analysis component } \\
0=\text { not present, } 1= \\
\text { adopt analysis from } \\
\text { other study, } 2= \\
\text { analysis within the } \\
\text { study }\end{array}$ & $\begin{array}{l}\text { - Downscaling climate change } \\
\text { scenario } \\
\text { - Impact of region's / local } \\
\text { activities contribute climate } \\
\text { change (e.g., GHG emission) } \\
\text { - Vulnerability assessment }\end{array}$ & $\begin{array}{l}\text { Spatial } \\
\text { implication of } \\
\text { climate change }\end{array}$ \\
\hline 3. & $\begin{array}{l}\text { Goals component } \\
0=\text { not present, } 1= \\
\text { present }\end{array}$ & $\begin{array}{l}\text { Objectives (Based on Sustainable } \\
\text { Development Principles) } \\
\text { - Harmony with nature } \\
\text { - Liveable built environment } \\
\text { - Place based economy } \\
\text { - Equity }\end{array}$ & $\begin{array}{l}\text { Emphasis } \\
\text { towards } \\
\text { sustainable } \\
\text { development } \\
\text { principles }\end{array}$ \\
\hline
\end{tabular}


Chee Ping Ngang, Joy Jacqueline Pereira \& Halimatonsaadiah Hashim

Integrating Climate Change Mitigation And Adaptation Into Spatial Planning: Developing Criteria For Spatial Plan Evaluation In The Selangor River Basin

\begin{tabular}{|c|c|c|}
\hline $\begin{array}{l}\text { 4. Policies component } \\
0=\text { not present, } 1= \\
\text { present but not } \\
\text { detailed, } 2=\text { present } \\
\text { and detailed/with } \\
\text { indicative map } \\
\text { (national)/diagram or } \\
\text { illustration (state)/map } \\
\text { (local) }\end{array}$ & $\begin{array}{l}\text { Land uses } \\
\text { - Development away from } \\
\text { vulnerable area (A) } \\
\text { - Disaster resistant communities } \\
\text { (A) } \\
\text { - Reduce urban sprawl (M) } \\
\text { - Infill development (M) } \\
\text { - Redevelopment of brown field } \\
\text { lands (M) } \\
\text { - Land use and urban design that } \\
\text { retain natural area (M\&A) }\end{array}$ & $\begin{array}{l}\text { Policy focus } \\
\text { based } \\
\text { planning subject }\end{array}$ \\
\hline & $\begin{array}{l}\text { Transportation } \\
\text { - Transit-oriented development and } \\
\text { corridor development } \\
\text { improvements (M) } \\
\text { - Integrated transportation system } \\
\text { (M) } \\
\text { - Parking standards adjustment (M) } \\
\text { Energy } \\
\text { - Promote energy efficiency/ } \\
\text { reduce energy dependency (M) } \\
\text { - Promote use of renewable energy } \\
\text { (M) } \\
\text { Waste } \\
\text { - Promote landfills with methane } \\
\text { capture strategy (M) } \\
\text { - Waste reduction developments } \\
\text { with high recycling strategy (M) }\end{array}$ & \\
\hline
\end{tabular}

Water

- Water use efficiency planning

(A)

- Coordination with river basin management (A)

- Storm water management/ Flood mitigation (A)

- Water demand management planning (A)

- Water supply management planning (A)

\section{$\underline{\text { Coast }}$}

- Coastal zone protection (A) 


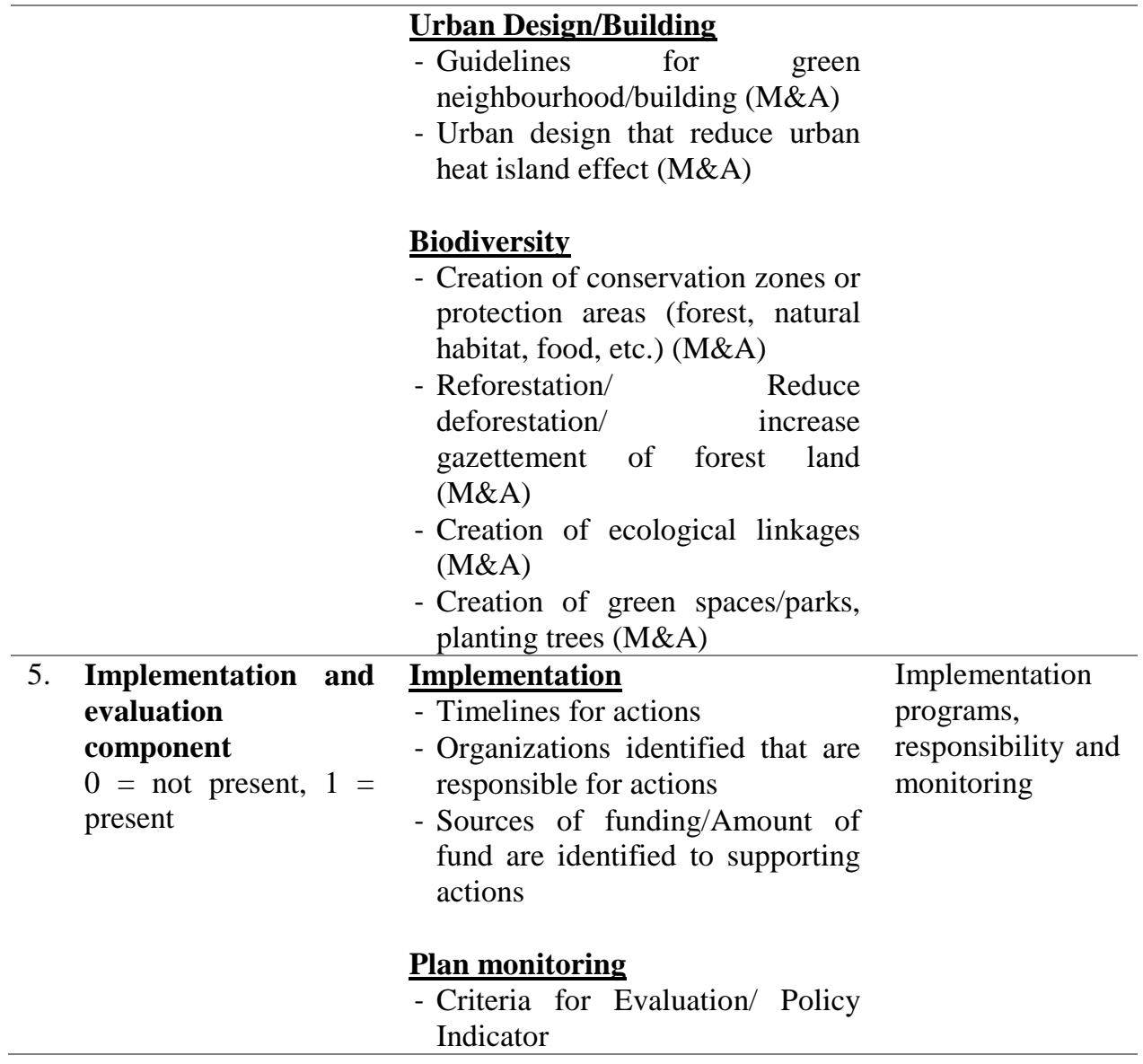

To answer the first research question in this study, there are three steps in the calculation of total plan quality (for climate change integration) for each plan. First, the equation for plan component score $\left(P C S_{j}\right)$ was created by summing up scores for each of the criteria $\left(C_{i}\right)$ within each of the plan components (equation 1). Where $P C S_{j}$ is the plan component score for the $j$ th component, and $m_{j}$ is the number of criteria within the $j$ th component.

$$
P C S_{j}=\sum_{i=1}^{m_{j}} C_{i}
$$

Second, the equation for plan component quality $\left(P C Q_{j}\right)$ was developed by standardizing the plan component score $\left(P C S_{j}\right)$ by dividing the possible score in each plan component $\left(2 m_{j}\right.$ or $\left.m_{j}\right)$ and multiplying the fractional score by 10 to place the component on a 0 to 10 scale (equation 2 and 3 ). 
Chee Ping Ngang, Joy Jacqueline Pereira \& Halimatonsaadiah Hashim

Integrating Climate Change Mitigation And Adaptation Into Spatial Planning: Developing Criteria For Spatial Plan Evaluation In The Selangor River Basin

For plan components which are scored on a $0-2$ scale,

$$
P C Q_{j}=\frac{10}{2 m_{j}} P C S_{j}
$$

For plan components which are scored on a $0-1$ scale,

$$
P C Q_{j}=\frac{10}{m_{j}} P C S_{j}
$$

Finally, the total plan quality $(T P Q)$ was gained by summing up all the plan component quality indices (equation 4). The maximum score for each plan is 50.

$$
T P Q=\sum_{j=1}^{5} P C Q_{j}
$$

For the second research question in this study, the calculation was done only for the policy component, where criteria within the policy component were categorized into three responses, namely, mitigation, adaptation, and both mitigation and adaptation. There are two steps in the calculation of an index for each response. First, the equation for response score $\left(R S_{k}\right)$ was created by summing up scores for each of the criteria $\left(C_{i}\right)$ within each of the response groups (equation 5). Where $R S_{k}$ is the response score for the $k$ th response, and $m_{k}$ is the number of criteria within the $k$ th response.

$$
R S_{k}=\sum_{i=1}^{m_{k}} C_{i}
$$

Second, the equation for Response Quality $\left(\mathrm{RQ}_{k}\right)$ was developed by standardizing the Response Score $\left(R S_{k}\right)$ by dividing the possible score in each response $\left(2 m_{k}\right)$ and multiplying the fractional score by 10 to place the component on a 0 to 10 scale (equation 6). Where $R Q_{k}$ is the response quality for the $k$ th response, and $m_{k}$ is the number of criteria within the $k t h$ response.

$$
R Q_{k}=\frac{10}{2 m_{k}} \sum_{i=1}^{m_{k}} C_{i}
$$

Data were further analysed using descriptive statistics to assess the quality of spatial plans based on three different levels (i.e., national, state and local). 
PLANNING MALAYSIA

Journal of the Malaysia Institute of Planners (2014)

\section{RESULTS}

The results from the plan evaluation above are presented based on two research questions previously mentioned. The first research question relates to the plan's overall quality in the planning process for climate change. The second research question allows for a comparison between the weight of climate change mitigation and adaptation policies in the spatial plans evaluated.

\section{To what extent have spatial plans in the Selangor River Basin prepared for climate change? Are there variations between spatial plans at the national, state and local level?}

Table 15 shows the overall results from the evaluation of spatial plans for the Selangor River Basin. Spatial plans at the national level scored the highest in total plan quality, followed by those at the state and local levels. The pattern is also echoed in the analysis based on each plan component (Figure 17). The state level plan scored as high as the national level plans in terms of goal and policy components, and in second place (after the national level) in terms of the fact component. Overall, the local level plans scored the least in all plan components, except in the implementation component. Evaluation at all levels shows the goal component scored the highest, followed by the policy, implementation, fact and analysis components. All three level plans scored fairly weak in analysis and fact components, with the plan quality ranging from 0 to 0.83 for the analysis component, and 0.48 to 3.93 for the fact component (out of the highest possible score of 10). This indicates that the evaluated plans cover not more than $8.3 \%$ of the criteria in the analysis component, and not more than $39.3 \%$ of the criteria in the fact component. The result indicates that the spatial plans generally provide room for climate change integration, particularly in goal, policy and implementation components, as the plans have held sustainable development as the guiding principles in the plan making process, and there are close connections between climate change management and sustainable development. However, since the scope of sustainable development in Malaysia has not included climate change explicitly, the relevant data and analysis are still not included in the spatial planning process, and this indirectly caused the assessment in fact and analysis integration of climate change in spatial planning to become relatively low. 
Chee Ping Ngang, Joy Jacqueline Pereira \& Halimatonsaadiah Hashim

Integrating Climate Change Mitigation And Adaptation Into Spatial Planning: Developing Criteria For Spatial Plan Evaluation In The Selangor River Basin

Table 15: Spatial plan quality for climate change integration in Selangor River Basin based on three levels of government

\begin{tabular}{lllll}
\hline & Plan Component Quality (PCQ) & National & State & Local \\
\hline 1. & Fact $^{\mathrm{a}}$ & 3.93 & 1.43 & 0.48 \\
\hline 2. & Analysis $^{\mathrm{a}}$ & 0.83 & 0 & 0 \\
\hline 3. & Goal $^{\mathrm{a}}$ & 7.14 & 7.14 & 5.71 \\
\hline 4. & Policy $^{\mathrm{a}}$ & 5.60 & 5.60 & 3.67 \\
\hline 5. & Implementation and evaluation $^{\mathrm{a}}$ & 6.25 & 2.50 & 5.00 \\
\hline & Total Plan Quality $^{\mathbf{b}}(\mathbf{T P Q})$ & $\mathbf{2 3 . 7 5}$ & $\mathbf{1 6 . 6 7}$ & $\mathbf{1 4 . 8 6}$ \\
\hline
\end{tabular}

${ }^{\mathrm{a}}$ Principle scores are scaled to 0-10

${ }^{\mathrm{b}}$ Highest possible score $=50$

\section{Percentage of performance $(\%)(\mathrm{TPQ} / 50 * 100)$}

\subsection{1}

33.34

29.71

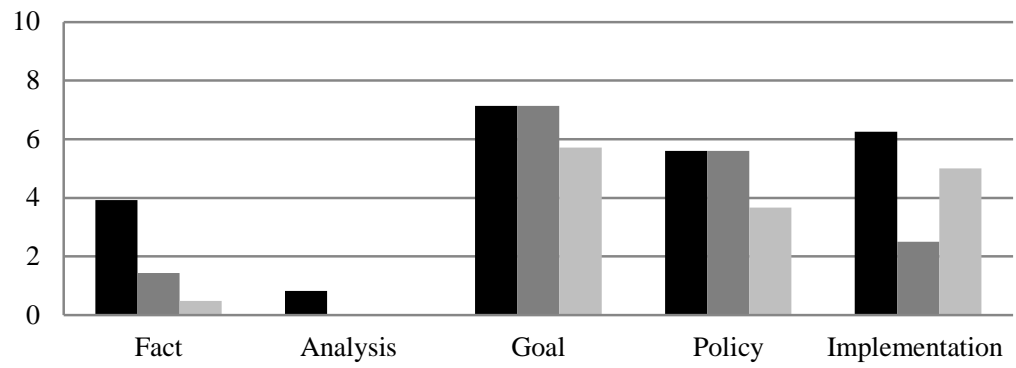

- National

- State

Local

Figure 17: Total plan quality for climate change integration

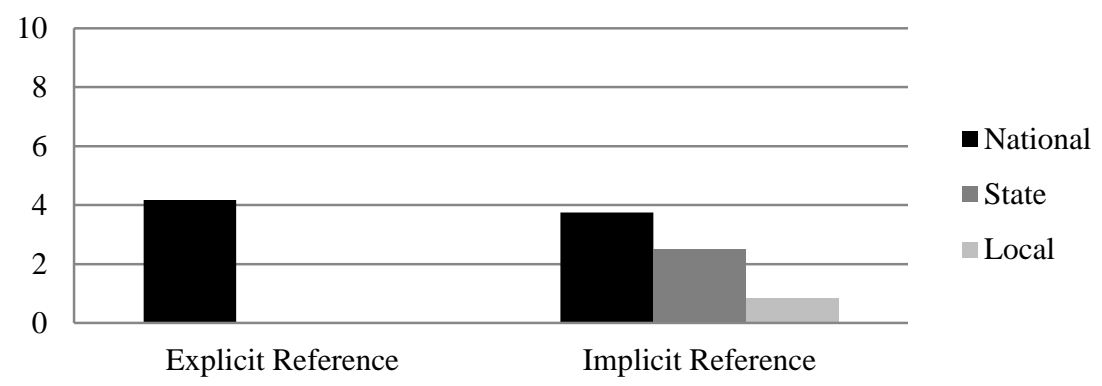

Figure 18: Plan quality for fact component 
The following sections compare the performance of spatial plans at three different levels in relation to fact, analysis, goal, policy and implementation/evaluation components.

\title{
FACT COMPONENT
}

The fact component in spatial plans at the three levels scored relatively low compared to the other plan components. As discussed earlier, spatial plans at the national level are more advanced in presenting the fact component, followed by those at the state and local levels (Figure 18). A comparison between the sub-components, which are explicit and implicit references, show that most of the facts in relation to climate change are presented implicitly in terms of rainfall data. Only national level spatial plans present explicit references to climate change, covering $41.7 \%$ of the criteria. However, there was less focus on the spatial implications of climate change, even at this level. On the other hand, the state and local level plans do not explicitly recognize climate change as an issue, and therefore lack in presenting data in relation to climate change. In terms of implicit references, the national level plans also scored the most, covering $37.5 \%$ of the subcomponent criteria, followed by the state level (14.3\%) and local level $(4.8 \%)$ plans. The temperature and rainfall intensity information were ignored in the plans at all three levels. Additionally, the state and local level plans do not cover sea level rise as one of the impending issues in spatial planning. The result is not surprising, since NPP2, which was prepared after the other five spatial plans, was the first planning document in Malaysia to acknowledge climate change. This impending issue is believed to have spatial implications, hence, should be considered during the early stage of spatial planning.

\begin{abstract}
ANALYSIS COMPONENT
The analysis component scored the least when compared to other plan components. The spatial plans at the state and local levels do not undertake analysis in relation to climate change. Only spatial plans at the national level include little vulnerability assessment due to sea level rise, based on secondary data from other studies (Figure 19). The analysis of the downscaling climate change scenario and impact of regional and local activities that contribute to climate change are also absent in the national level plans.
\end{abstract}


Chee Ping Ngang, Joy Jacqueline Pereira \& Halimatonsaadiah Hashim

Integrating Climate Change Mitigation And Adaptation Into Spatial Planning: Developing Criteria For

Spatial Plan Evaluation In The Selangor River Basin

\section{GOAL COMPONENT}

The goal component is the highest plan component considered by the spatial plans in the study area. Sustainable development is cited explicitly in all spatial plans at the three levels, particularly at the national and state levels, and recognized as the guiding principle in the spatial plans. Figure 5 shows that the national and state level spatial plans present a full score in the goal component, while local spatial plans have an average score of 3.33 (out of 10). The lower score in local level spatial plans is due to the emphasis of the two spatial plans on economic development and city liveability. For the objective sub-component, spatial plans at all levels have a fairly equal score, with more emphasis on the sustainable development principles of: i) harmony with nature; ii) liveable built environment; iii) place based economy; and iv) equity. Two principles that are completely disregarded by all of the spatial plans are the polluters pay principle and the responsible regionalism principle. A comparison between the two sub-components of goal statement and objectives indicates that the national and state level spatial plans excel in goal statement but weak in objectives. On the other hand, the local level spatial plans have a low score in goal statement, but have a high score in the objective sub-components.

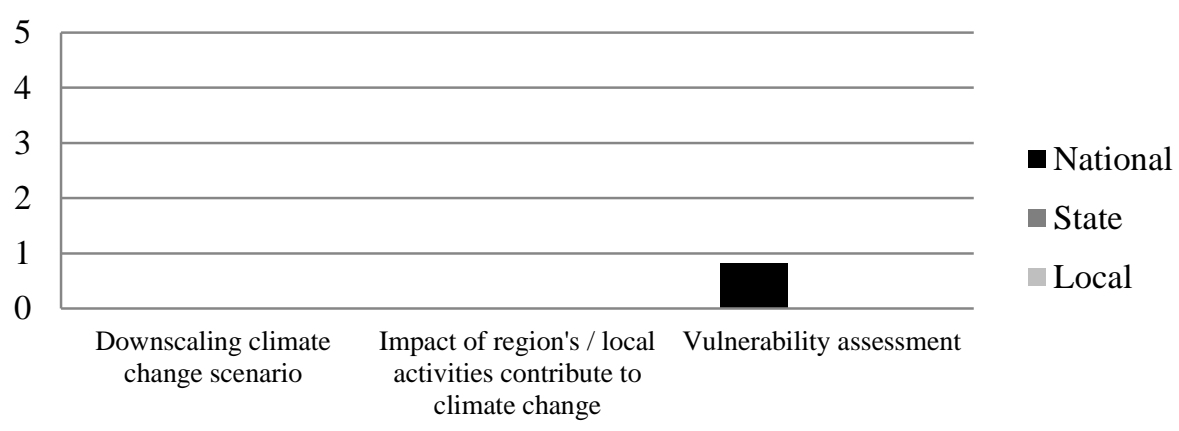

Figure 19: Plan quality for analysis component 
PLANNING MALAYSIA

Journal of the Malaysia Institute of Planners (2014)

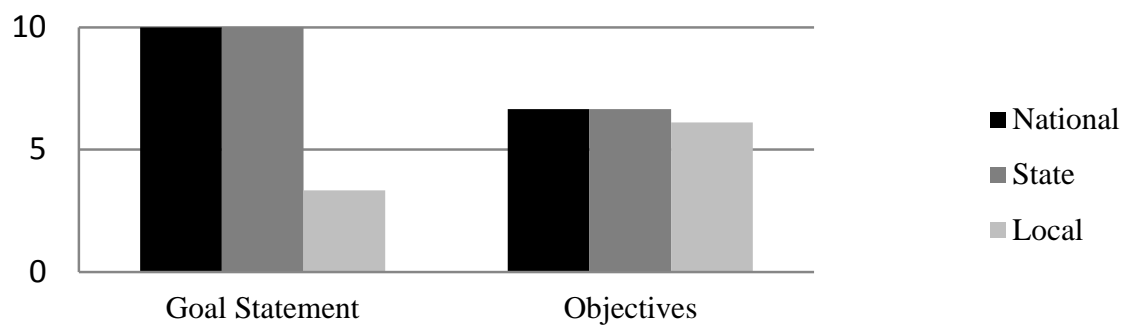

Figure 20: Plan quality for goal component

\section{POLICY COMPONENT}

Generally, the policy component is the second highest plan component being considered by the spatial plans in the study area, and directly follows the goal component. Compared to other plan components, this component scores the second highest in the state level spatial plan, and the third highest in the national and local level spatial plans (Figure 17). The scores for the national and state level plans are the same, covering 56\% of the policy component criteria. However, the local level plans score slightly lower than the upper two levels, i.e., only covering $36.7 \%$ of the criteria. Figure 6 shows the plan quality for the policy component based on a standardized score for each plan sub-component. From Figure 21, a general pattern is observed where the national and state level plans include more policies than the local level plans in relation to climate change (except in the subcomponent of urban design/building). Biodiversity is the most emphasized sub-component, followed by transportation, coastal planning and land use planning. Nonetheless, planning for waste, which includes promoting landfills with methane capture strategy and waste reduction developments, is completely ignored in all spatial plans. The energy plan sub-component is only considered in spatial plans at the national level, but absent at the state and local levels. The state level spatial plan is more advanced in water resources planning, i.e., slightly higher than the national level plan.

\section{IMPLEMENTATION AND EVALUATION}

The implementation and evaluation component had relatively average scores, with spatial plans at the national level covering $62.5 \%$ of the criteria, local level plans covering $50 \%$, and state level plans covering $25 \%$. The implementation sub-component is more advanced at the local level, followed by the national and state levels (Figure 7). The state level plan lacks in setting up timelines for actions and identifying sources of funding. 
Chee Ping Ngang, Joy Jacqueline Pereira \& Halimatonsaadiah Hashim

Integrating Climate Change Mitigation And Adaptation Into Spatial Planning: Developing Criteria For Spatial Plan Evaluation In The Selangor River Basin

For the sub-component of plan evaluation, only spatial plans at the national level include criteria for plan evaluation.

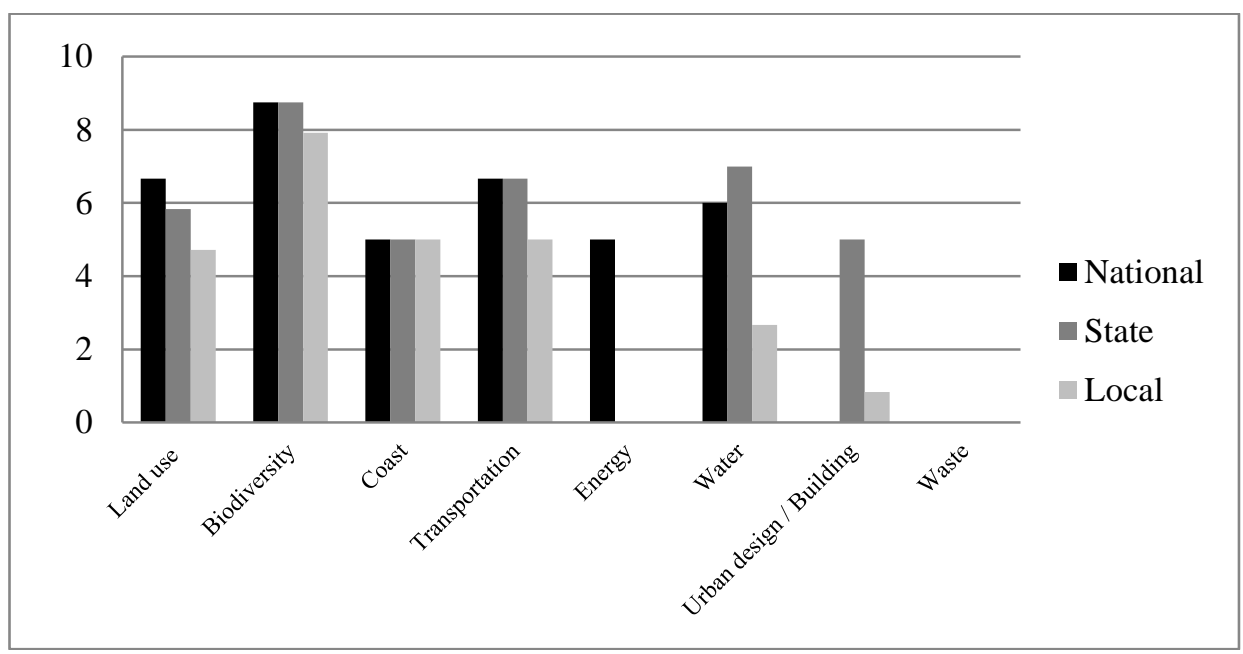

Figure 21: Plan quality for policy component

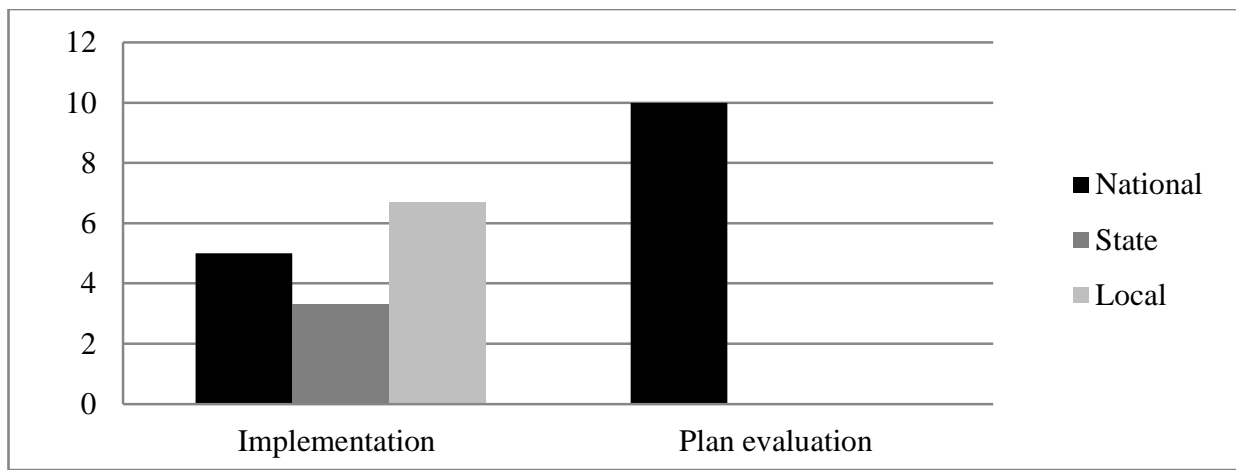

Figure 22: Plan quality for implementation and evaluation component 


\section{Do the spatial plans pay an equal amount of attention to climate change mitigation and adaptation?}

Collectively, all three levels of spatial plans pay an equal amount of attention to both climate change mitigation and adaptation (Figure 23). Among the three types of responses, spatial plans place more attention to policies that integrate climate change mitigation and adaptation, accounting to $44 \%$ of the total responses. Figure 34 shows the focus of spatial plans at different levels by standardizing the scores between climate change mitigation, climate change adaptation and both mitigation and adaptation. The differences between climate change mitigation and adaptation are not much, ranging from only 2\% (for the national and local level) and 3\% (for the state level). All plans at the three levels consistently show emphasis on the integration between both climate change mitigation and adaptation. Comparatively, the national level spatial plan is more advanced in mitigation measures due to its attention to the energy aspect. On the other hand, the state level plan achieves more in adaptation as a result of its focus on water efficiency and water supply planning. The roughly equal amount of attention to both responses support the argument that spatial planning can actually coordinate effective mitigation and adaptation responses in an integrated manner through sustainable development policies (Biesbroek et al., 2009).

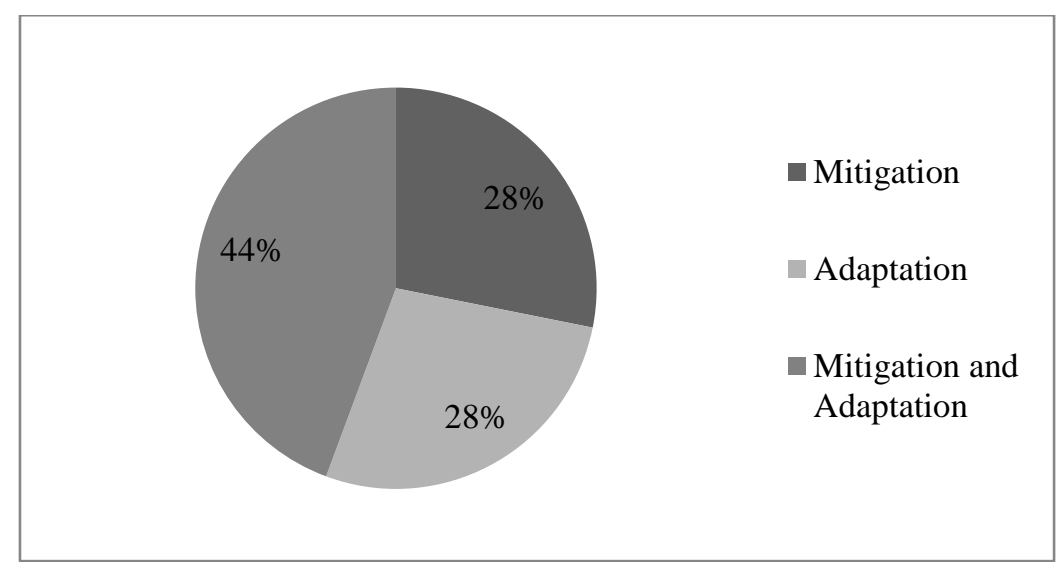

Figure 23: Overall planning responses to climate change 
Chee Ping Ngang, Joy Jacqueline Pereira \& Halimatonsaadiah Hashim Integrating Climate Change Mitigation And Adaptation Into Spatial Planning: Developing Criteria For Spatial Plan Evaluation In The Selangor River Basin

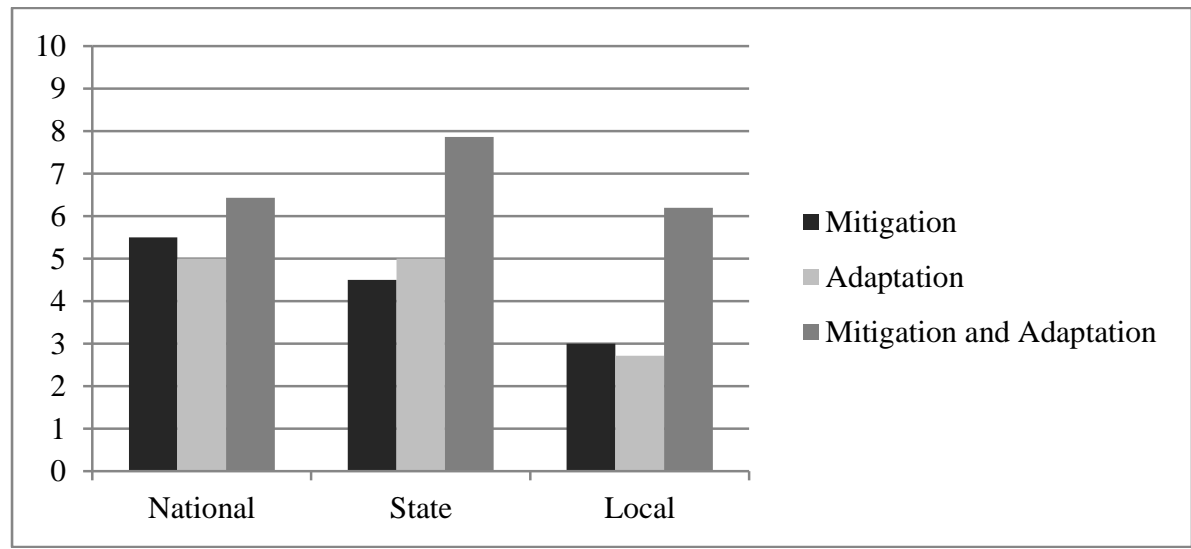

Figure 24: Comparison of planning responses to climate change at national, state and local levels

\section{THE GAPS}

By referring to Figure 17, the main gaps for all the spatial plans are fact and analysis components, and this is most apparent at the state and local levels. The other three plan components, which are the goal, policy and implementation components, also need to be strengthened by the reframing of sustainable development in the context of Malaysia. All spatial plans fail to utilize temperature and rainfall intensity data in shaping future land use developments. The spatial implications of climate change due to changing temperature and rainfall patterns are also in need of serious attention. In terms of analysis, spatial plans at all levels need to be improved on vulnerability assessment as a result of climate change, impact of local activities which can contribute to climate change, and the application of downscaling climate change scenario in its future land use planning. In addition, all spatial plans need to include waste planning, which include the promotion of landfills with the methane capture strategy and waste reduction development in future plan reviews to effectively respond to climate change. Compared to others, spatial plans at the national level lack the promotion of green neighbourhood and urban design that can reduce the Urban Heat Island (UHI) effect. Relatively, spatial plans at the state and local levels are deficient in terms of planning for disaster resistant communities, water demand management and including criteria for plan implementation/evaluation. 


\section{CONCLUSION}

This study provides a systematic evaluation of how well spatial plans in the Selangor River Basin respond to climate change across various critical components that define the quality of the plans, including facts, analysis, goals, policies and implementation. The first set of findings reveal that the spatial plan quality is higher at the national level, but gradually declines in the lower tiers. This finding is not surprising, because NPP2, with explicit consideration of climate change, was prepared after the other plans. Nonetheless, lower plan quality at the local level, compared to the state level, is in need of serious attention as to why some of the data, analysis or policies on climate change in the higher level plans are not being utilized and refined at the local level. The second set of findings show that all of the spatial plans generally give an equal emphasis to climate change mitigation and adaptation. This supports the argument that spatial planning provides platforms for coordinating mitigation and adaptation responses through its sustainable development policies (Biesbroek et al., 2009).

This research extends the literature of plan quality evaluation by incorporating the Planning Process Model as the basis for the plan assessment process. In addition, the assessment involved both mitigation and adaptation responses at three different levels of jurisdiction, compared to previous studies, which mostly focus on either mitigation or adaptation, and at only one level of administration. The criteria, plan evaluation protocol and the quantitative assessment of plans can be adapted to other river basins with some improvement to the evaluation criteria based on the local context of climate change impact. It can also be used by planners in the future to track changes in plans over time, and the degree to which this change leads to improved outcomes. The evaluation is vital to identify the gaps towards climate change integration, and could assist in resource allocation in the future for the mainstreaming of climate change in spatial planning.

\section{REFERENCES}

Baer, W.C. (1997). General Plan Evaluation Criteria: An Approach to Making Better Plans. Journal of the American Planning Association, 63(3),329-342.

Barbour, E. andKueppers, L. M. (2012). Conservation and Management of Ecological Systems in a Changing California. Climatic Change,111(1), 135-163.

Beck, L., and Bernauer, T. (2011). How Will Combined Changes in Water Demand and Climate Affect Water Availability in the Zambezi River Basin? Global Environmental Change, 21, 1061-1072. 
Chee Ping Ngang, Joy Jacqueline Pereira \& Halimatonsaadiah Hashim

Integrating Climate Change Mitigation And Adaptation Into Spatial Planning: Developing Criteria For Spatial Plan Evaluation In The Selangor River Basin

Berke, P.R. (1996). Enhancing Plan Quality: Evaluating the Role of State Planning Mandates for Natural Hazard Mitigation. Journal of Environmental Planning and Management, 39(1), 79-96.

Berke, P.R. (1998). Reducing Natural Hazard Risks through State Growth Management. Journal of the American Planning Association, 64(1),76-87.

Berke, P.R., and French, S.P. (1994). The Influence of State Planning Mandates on Local Plan Quality. Journal of Planning Education and Research,13, 237-250.

Berke, P.R., and Conroy, M.M. (2000) Are We Planning for Sustainable Development? An Evaluation of 30 Comprehensive Plans. Journal of American Planning Association, 66(1), 21-33.

Berke, P.R., and Godschalk, D. (2009). Searching for the Good Plan: A Meta-Analysis of Plan Quality Studies. Journal of Planning Literature, 23(3),227-240.

Biesbroek, G.R., Swart, R.J., and Kanapp, W.G.M. (2009). The Mitigation-Adaptation Dichotomy and the Role of Spatial Planning. Habitat International, 33,230-237.

Blanco, H., and Alberti, M. (2009). Building Capacity to Adapt to Climate Change through Planning. In. Hot, Congested, Crowded and Diverse: Emerging Research Agendas in Planning. Progress in Planning, 71, 158-169.

Boult, B. (2009). Water Management. In Adaptation to Climate Change: A Spatial Challenge, Rob Roggema, eds. Dordrecht : Springer Publisher. 183-210.

Brody, S.D. (2003a). Are We Learning to Make Better Plans? : A Longitudinal Analysis of Plan Quality Associated with Natural Hazards. Journal of Planning Education and Research, 23,191-201.

Brody, S.D. (2003b). Measuring the Effects of Stakeholder Participation on the Quality of Local Plans based on the Principles of Collaborative Ecosystem Management. Journal of Planning Education and Research, 22,407-419.

Brody, S.D., Carasco, V., and Highfield, W.E. (2006). Measuring the Adoption of Local Sprawl: Reduction Planning Policies in Florida. Journal of Planning Education and Research, 25, 294-310.

Brown, M.A., Southworth, F., and Sarzynski, A. (2009).The Geography of Metropolitan Carbon Footprints. Policy and Society, 27,285-304.

Bruton, M.J. (2007).Malaysia: The Planning of a Nation. Malaysia: PERSADA.

Bulkeley, H. (2006). A Changing Climate for Spatial Planning. Planning Theory and Practice, 7(2), 203-214.

Davoudi, S., Crawford, J., and Mehmood, A. (2009). Planning for the Climate Change: Strategies for Mitigation and Adaptation for Spatial Planners. London: Earthscan.

Department for Communities and Local Government (DCLP).(2007). Planning Policy Statement: Planning and Climate Change - Supplement to Planning Policy Statement 1. United Kingdom.

Driscoll, D. A., Felton, A., Gibbons, P., Felton, A. M., Munro, N. T. and Lindenmayer, D. B. (2012). Priorities in Policy and Management When Existing Biodiversity Stressors Interact with Climate-Change. Climatic Change,111(3-4), 533-557.

Erol, A., and Randhir, T.O. (2012). Climatic Change Impacts on the Eco Hydrology of Mediterranean Watersheds. Climatic Change, 114(2), 319-341. 
PLANNING MALAYSIA

Journal of the Malaysia Institute of Planners (2014)

European Commission. (1997). The EU Compendium of Spatial Planning Systems and Policies. Brussels, European Union.

Faludi, A. (2000). The Performance of Spatial Planning. Planning Practice and Research, 15(4), 299-318.

Giridharan, R., Lau, S.S.Y., Ganesan, S., and Givoni, B. (2007). Urban Design Factors Influencing Heat Island Intensity in High-Rise High-Density Environments of Hong Kong. Building and Environment, 42, 3669-3684.

Grazi, F.,\& van den Bergh, J. C. J. M. (2008). Spatial organization, transport, and climate change: Comparing instruments of spatial planning and policy. Ecological Economics,67(4), 630-639.

Gurran, N., Norman, B.,and Hamin, E. (2013). Climate Change Adaptation in Coastal Australia: An Audit of Planning Practice. Ocean \& Coastal Management,86, $100-109$.

Jusuf, S.K., Wong, N.H., Hagen, E., Anggoro, R., and Hong, Y. (2007) The Influence of Land Use on the Urban HeatIsland in Singapore. Habitat International, 31, 232242.

Kabat P (2009) Create Space for Climate! InAdaptation to Climate Change: A Spatial Challenge, Rob Roggema, eds. Dordrecht : Springer Publisher. 1-57.

Kaiser, E.J., Godschalk, D.R., and Chapin, F.S. (1995). Urban Land Use Planning, $4^{\text {th }}$ Ed. Urbana: University of Illinois Press.

Keeffe, G. (2009). The Urban Environment. InAdaptation to Climate Change: A Spatial Challenge, Rob Roggema, eds. Dordrecht : Springer Publisher. 289-318.

Levett, R. (2006). Planning for Climate Change: Reality Time? Planning Theory and Practice, 7(2), 214-218.

Lu, P. \& Stead, D. (2013). Understanding the Notion of Resilience in Spatial Planning: A Case Study of Rotterdam, The Netherlands. Cities,35, 200-212.

Ministry of Natural Resources and Environment (NRE). (2009). National Policy on Climate Change. Malaysia.

Ministry of Natural Resources and Environment (NRE). (2011). National Communication 2. Malaysia.

Nicholls, R.J. (2011). Planning for the Impacts of Sea Level Rise. Oceanography, 24(2), 144-157.Norton, R.K. (2008). Using Content Analysis to Evaluate Local Master Plans and Zoning Codes. Land Use Policy, 25, 432-454.

Norton, R.K. (2008). Using Content Analysis to Evaluate Local Master Plans and Zoning Codes. Land Use Policy,25(3), 432-454.

Peltonen, L., Haanpaa, S., and Lehtonen, S. (2005) The Challenge of Climate Change Adaptation in Urban Planning. FINADAPT Working Paper 13, Finnish Environment Institute Mimeographs 343, Helsinki, pp 44.

Permana, A.S., Norsiah, A.A., and Abd. Razak, J. (2013). Potential Urban Development Parameters That Reduce Energy Consumption in Residential Area. Journal of Planning Malaysia: Geospatial Anaysis in Urban Planning, volume II, 101-118.

Pettersson, M.,and Keskitalo, E. C. H. (2013). Adaptive Capacity of Legal and Policy Frameworks for Biodiversity Protection Considering Climate Change. Land Use Policy,34, 213-222.

Pinto, R. \&Martins, F. C. (2013). The Portuguese National Strategy for Integrated Coastal Zone Management as a Spatial Planning Instrument to Climate Change 
Chee Ping Ngang, Joy Jacqueline Pereira \& Halimatonsaadiah Hashim

Integrating Climate Change Mitigation And Adaptation Into Spatial Planning: Developing Criteria For Spatial Plan Evaluation In The Selangor River Basin

Adaptation in the Minho River Estuary (Portugal NW-Coastal Zone). Environmental Science \& Policy,33, 76-96.

Robinson, P. (2006). Canadian Municipal Response to Climate Change: Measurable Progress and Persistent Challenges for Planners. Planning Theory and Practice, 7(2), 218-223.

Schmidt-Thome, P. (2006). Integration of Natural Hazards, Risk and Climate Change into Spatial Planning Practices. Academic Dissertation.

Selangor State Government. (2007). Sungai Selangor Basin Management Plan 2007 2012. Malaysia.

Sovacool, B.K., and Brown, M.A. (2010). Twelve Metropolitan Carbon Footprints: A Preliminary Comparative Global Assessment. Energy Policy, 38, 4856-4869.

Stone, B. Jr. (2005). Urban Heat and Air Pollution: An Emerging Role for Planners in the Climate ChangeDebate. Journal of the American Planning Association, 71(1), 13-25.

Tang, Z., Brody, S.D., Quinn, C., Chang, L., and Wei, T. (2010). Moving from Agenda to Action: Evaluating Local Climate Change Action Plans. Journal of Environmental Planning and Management, 53(1), 41-62.

Urwin, K.,and Jordan, A. (2008). Does Public Policy Support or Undermine Climate Change Adaptation? Exploring Policy Interplay Across Different Scales of Governance. Global Environmental Change,18(1), 180-191.

Wendea, W., Huelsmanna, W., Martya, M., Penn-Bressela, G., andBobylevb, N. (2010). Climate Protection and Compact Urban Structures in Spatial Planning and Local Construction Plans in Germany. Land Use Policy, 27, 864-868.

Wheeler, S. M. (2008). State and Municipal Climate Change Plans: The First Generation. Journal of the American Planning Association, 74(4), 481-496.

Wheeler, S.M., Randolph, J., and London, J.B. (2009). Planning and Climate Change: An Emerging Research Agenda. In. Shaken, Shrinking, Hot, Impoverished and Informal: Emerging Research Agendas in Planning. Progress in Planning, 72, $195-250$

Wilson, E. (2006). Adapting to Climate Change at the Local Level: The Spatial Planning Response. Local Environment, 11(6), 609-625.

Wilson, E., and Piper, J. (2010). Spatial Planning and Climate Change. Toronto: Routledge.

Wong, N.H., and Chen, Y. (2005) Study of Green Areas and Urban Heat Island in ATropical City. Habitat International, 29, 547-558. 